\title{
Journey to the Future of Family Medicine
}

\author{
Paul A. Nutting, MD, MSPH, Associate Editor \\ Ann Fam Med 2008;6:270-272. DOI: 10.1370/afm.855.
}

$F^{a}$ amily medicine has entered a fascinating period of transition and rebirth. In 2004 the Annals was pleased to publish the Future of Family Medicine (FFM) report ${ }^{1}$ and to track the rich discussion of family physicians in practice, academia, research, and policy. ${ }^{2}$ The FFM report quickly spawned the TransforMED National Demonstration Project (NDP), supported by the American Academy of Family Physicians (http://www.transformed.com/ and http://www.transformed.com/ndp.cfm). The NDP recruited 36 family practices selected from an applicant pool of more than 300 across the United States. For evaluation purposes, the practices were randomized to intervention and self-directed groups. During a 2-year period, the intervention group has been receiving intensive assistance from an NDP facilitator, access to consultants, discounted support in implementing information technology, and 3 retreats for sharing experiences. The selfdirected comparison group has access to information about the improvement tools from the NDP Web site, but no hands-on facilitation, access to consultants, or the practice retreats.

The components of the New Model envisioned by the FFM report are not simple to implement, nor is their effectiveness in improving patient care known. The NDP is therefore an important experiment in understanding the requirements and the benefits of the practice models suggested by the FFM report. Five articles in last issue addressed the challenges faced by practice transformation. In response, Annals' readers have been busy reading, reflecting, and commenting on the many challenges we face in this journey.

\section{THE NATIONAL DEMONSTRATION PROJECT (NDP)}

In an essay Drs. Loxterkamp and $\mathrm{Kazal}^{3}$ from 2 of the self-directed practices describe early progress and a retreat organized by the self-directed practices themselves. This article generated a great deal of commentary, including further context and explanation of the NDP by McMillen, ${ }^{4}$ Executive Director of TransforMED, and Stewart, ${ }^{5}$ from the TransforMED Evalu- ation Team. They summarize some of the early lessons from the NDP, including this one:

Many of the products and services are nowhere near ready for prime time. Technology is one example. We have learned that not only are some technology products not "family physician friendly," we've learned that even exemplar practices may not be ready to absorb the new stressors that new technology can bring. ${ }^{4}$

A stimulating body of commentary comes as well from the practices of the NDP. ${ }^{6-11}$ They speak to the courage of physicians and their staff and their enthusiasm for taking on the arduous task of transforming their practice because they know that will be good for their patients. Harrington ${ }^{11}$ provides a glimpse of his vision of his practice of the future. Both Kollman ${ }^{8}$ and Rickard ${ }^{10}$ point out that such a radical transformation cannot be accomplished in only 2 years; it is part of an ongoing journey. Toms, ${ }^{7}$ a registered nurse in one of the practices, gently reminds us that the teamwork of and relationships among the entire practice staff determine how patients experience their care. We too often forget that family medicine is a team event. Continuing our physician-centric view of the transformation of family practice will not serve us well as we move into the future.

One of the understandings emerging from the NDP is that there is more than one single model of the Primary Care Medical Home. Gerard ${ }^{12}$ and Silk ${ }^{13}$ point out that the NDP does not explicitly address the family and argue for a family room in the medical home. Scott ${ }_{1}^{14}$ Rickard, ${ }^{10}$ and $\operatorname{Han}^{15}$ point out that the specific elements of the New Model are just tools to be joined with relationship-centered care on the journey toward a "healing practice." They remind us that being patientcentered is not enough-our visions of the medical home should be "relationship-centered." Loxterkamp says this well in a later commentary:

We enter into therapeutic relationships with our patients in which we give a little of ourselves and allow them to feel befriended, cared for, brooded over, and guarded. This is not patient-centered care, or basket-of-services care, but relationship-centered care, something my father understood and our patients value most. ${ }^{16}$ 
Despite the extreme difficulty of their transformation efforts, the dedication and enthusiasm of the practices are infectious. Hawley and his partners ${ }^{9}$ comment:

This is a great time to be a family physician and not a time for despair! We have many options for improving our practice environments, if we are willing to undertake these tasks with a large dose of creativity, humility and courage.

In speaking of his vision of the future, Harrington ${ }^{11}$ concludes:

Even though the wicked 3rd party of the west still doesn't pay us well, and we still have to see more patients than ever, that bothers us less, because in that land we have more time for decision making and for building therapeutic relationships with patients.

\section{PRACTICE REDESIGN}

The study by Haggerty et a ${ }^{17}$ examined the attributes that are associated with accessibility, continuity, and coordination of care, which often compete with each other. They found that the way a clinic is organized allows physicians to achieve both accessibility and continuity rather than having one compete with the other. In the context of the transformation of family practice, Haggerty's study reassures us that modifying the structural/procedural characteristics of a practice can improve care in important ways. Fortin ${ }^{18}$ notes the timeliness of the study in light of important primary care reform in Quebec. Moore ${ }^{19}$ expresses relief that a number of practices in the study rejected "Sophie's choice" and instead asked, "Why force us to choose between valuable attributes? Why can we not have them all?" Wall ${ }^{20}$ emphasizes the importance of care teams and notes:

The term "medical home" is thrown around today a great deal. It alludes not to the family practices of the past, where coordination was physician-dependant, but to the family practices of the future where real systems and processes work in concert with teams of care providers to address access, continuity and accountability in different ways.

\section{RELATIONSHIP-CENTERED CARE}

The patient-physician relationship is the central element of family practice and a centerpiece of the Future of Family Medicine report. ${ }^{1}$ A lively discussion continues around an article published in the January/February issue of Annals in which Berry et al gave us more evidence of the importance of the patient-physician relationship, and showed that trust and commitment to the relationship influence how patients accept and act on our advice. ${ }^{21}$
Tarrant ${ }^{22}$ identifies some trends in the National Health Service of the United Kingdom that may undermine the patient-physician relationship. Haws ${ }^{23}$ places the study results in the context of other behavioral science principles. Wilkinson, ${ }^{24}$ a medical student from Texas $A \& M$, notes that "innovation is not what we are taught in medical school," and suggests that current medical education practices (timed interviews) may not prepare physicians for a rich patient relationship. The need for further research is addressed by Howley, ${ }^{25}$ who identifies some related research questions, and Kerse, ${ }^{26}$ who emphasizes the need to move from descriptive to intervention studies of the clinical effects of the patient-physician relationship.

\section{STRESS AND BURNOUT}

Transforming a traditional family practice to a New Model envisioned by the Future of Family Medicine report is a huge undertaking, and one that creates stress for physicians and their practice staff. Two articles in the last issue address important concerns of physicians taking care of themselves and protecting themselves from burnout.

In a compelling essay, Carrese and Ibrahim ${ }^{27}$ address the challenges facing physicians today as they struggle to strike a sense of balance between career and personal life.

Cunningham, ${ }_{1}^{28}$ Hensel, ${ }^{29}$ and Elder ${ }^{30}$ remind us that finding balance is a personal choice, while Katerndah ${ }^{31}$ points out that "balance is a matter of focus" and describes how that principle has helped him deal with the issues described in the essay. Baumer ${ }^{32}$ notes that family medicine is all about relationships, whether they be with our patients, colleagues, or families.

Mechaber, ${ }^{33}$ Beste, $_{1}^{34}$ Warde, ${ }^{35}$ and Gadon ${ }^{36}$ note that demands of academic medicine are fierce for those seeking balance. They encourage academic leadership both to "catch up with what is needed by up and coming physicians" ${ }^{\prime \prime}$ and "embrace current efforts underway to promote flexibility in career trajectories." ${ }^{133}$

In a study that points the way toward a possible solution for finding balance through reflection, Kjeldmand and Holmstrom ${ }^{37}$ studied Balint groups as a strategy to increase job satisfaction and prevent burnout among primary care physicians.

Benbassat ${ }^{38}$ and Brock and Freedy ${ }^{39}$ address the generalizabilty of the study to the larger population of primary care physicians, and the latter describe their experiences both as leaders and participants in Balint groups.

Margalit ${ }^{40}$ suggests that frustration and burnout may derive in part from the inability of many family physicians to deal effectively with the many biopsychosocial problems in primary care practice. 
He points out that there may be other strategies for reducing physician stress and burnout and summarizes a study that taught biopsychosocial skills and demonstrated reduced burnout.

In discussing Balint groups as "self-care for care givers," Buchbinder ${ }^{41}$ notes that "if you don't take care of yourself, you won't be able to take care of others." She also points us to further information about Balint groups (http://americanbalintsociety.org/pdf/WhatToExpectBrochure.pdf).

Please join the discussion at http://www.AnnFamMed. org.

\section{References}

1. Martin JC, Avant RF, Bowman MA, et al. The future of family medicine: a collaborative project of the family medicine community. Ann Fam Med. 2004;(2)(Suppl 1):S3-S32.

2. Stange KC. The future of family medicine? Reflections from the front lines reveal frustration and opportunity. Ann Fam Med. 2004;2(3):274-277

3. Loxterkamp D, Kazal LA Jr. Changing horses midstream: the promise and prudence of practice redesign. Ann Fam Med. 2008;6(2):167-170

4. McMillen MA. The NDP journey: a TransforMED perspective [eletter] http://www.annfammed.org/cgi/eletters/6/2/167\#8346, 3 Apr 2008.

5. Stewart EE. From knowing to believing: two groups, one journey [eletter]. http://www.annfammed.org/cgi/eletters/6/2/167\#8261, 24 Mar 2008.

6. Lockman AR. Reaching for the revolution [eletter]. http://www. annfammed.org/cgi/eletters/6/2/167\#8327, 2 Apr 2008.

7. Toms BC. Family medicine specialty, nursing point of view [eletter]. http://www.annfammed.org/cgi/eletters/6/2/167\#8320, 2 Apr 2008

8. Kollman RD. Why the journey [eletter]? http://www.annfammed. org/cgi/eletters/6/2/167\#8318, 31 Mar 2008.

9. Hawley $C$, et al. Embracing the journey of a family physician [eletter] http://www.annfammed.org/cgi/eletters/6/2/167\#8303, 31 Mar 2008.

10. Rickard RC. Patient-centered medical homes [eletter]. http://www. annfammed.org/cgi/eletters/6/2/167\#8178, 15 Mar 2008.

11. Harrington WG. Where is this trail ride headed [eletter]? http:// www.annfammed.org/cgi/eletters/6/2/167\#8136, 14 Mar 2008.

12. Gerard RJ. Family room [eletter]. http://www.annfammed.org/cgi/ eletters/6/2/167\#8092, 11 Mar 2008.

13. Silk HJM. Prescription for change [eletter]. http://www.annfammed. org/cgi/eletters/6/2/167\#8180, 18 Mar 2008.

14. Scott JG. Healing practices [eletter]. http://www.annfammed.org/ cgi/eletters/6/2/167\#8167, 15 Mar 2008.

15. Han JK. Healing occurs within relationships [eletter]. http://www. annfammed.org/cgi/eletters/6/2/167\#8164, 15 Mar 2008.

16. Loxterkamp DA. Response to Bonita Toms [eletter]. http://www. annfammed.org/cgi/eletters/6/2/167\#8351, 4 Apr 2008.

17. Haggerty JL, Pineault $R$, Beaulieu $M$, et al. Practice features associated with patient-reported accessibility, continuity, and coordination of primary health care. Ann Fam Med. 2008;6(2):116-123.

18. Fortin M. Exploratory maybe but rich nonetheless [eletter]. http:// www.annfammed.org/cgi/eletters/6/2/116\#8113, 14 Mar 2008.
19. Moore LG. Must we accept Sophie's choice [eletter]? http://www. annfammed.org/cgi/eletters/6/2/116\#8142, 14 Mar 2008.

20. Wall EM. Practice organization and continuity of care [eletter]. http:// www.annfammed.org/cgi/eletters/6/2/116\#8103, 14 Mar 2008.

21. Berry LL, Parish JT, Janakiraman R, et al. Patients' commitment to their primary physician and why it matters. Ann Fam Med. 2008;6(2):6-13

22. Tarrant CC. The value of commitment: A UK perspective [eletter]. http://www.annfammed.org/cgi/eletters/6/1/6\#7978, 3 Mar 2008.

23. Haws KL. Patients' self-control over their behaviors [eletter]. http:// www.annfammed.org/cgi/eletters/6/1/6\#7995, 5 Mar 2008.

24. Wilkinson JB. Time limits in training may hamper future patientphysician relationships [eletter]. http://www.annfammed.org/cgi/ eletters/6/1/6\#7951, 3 Mar 2008

25. Howley MJ. Thoughts on "A Patients' Commitment to their Primary Physician and Why it Matters" [eletter]. http://www.annfammed. org/cgi/eletters/6/1/6\#7636, 21 Jan 2008

26. Kerse N. The doctor-patient relationship; time for intervention research [eletter]. http://www.annfammed.org/cgi/eletters/6/1/6\#7755, 11 Feb 2008

27. Carrese JA, Ibrahim MA. Success, regret, and the struggle for balance. Ann Fam Med. 2008;6(2):171-172.

28. Cunningham JA. The tougher balance is between me and others [eletter]. http://www.annfammed.org/cgi/eletters/6/2/171\#8222, 19 Mar 2008.

29. Hensel A. To thine own self [eletter], http://www.annfammed.org/ cgi/eletters/6/2/171\#8248 21 Mar 2008.

30. Elder NC. The struggle for balance never ends [eletter]. http://www. annfammed.org/cgi/eletters/6/2/171\#8111, 11 Mar 2008.

31. Katerndahl D. Whose "family" in family medicine [eletter]. http:// www.annfammed.org/cgi/eletters/6/2/171\#8195, 18 Mar 2008.

32. Baumer J. Is it balance or expectations [eletter]? http://www. annfammed.org/cgi/eletters/6/2/171\#8209, 18 Mar 2008.

33. Mechaber HF. Experienced leaders can help promote balance for new generation of physician leaders [eletter]. http://www. annfammed.org/cgi/eletters/6/2/171\#8157, 14 Mar 2008.

34. Beste JF. Success, regret, and the struggle for balance [eletter]. http:// www.annfammed.org/cgi/eletters/6/2/171\#8211, 18 Mar 2008.

35., Warde CM. Leadership courage promote change toward a more compassionate academic medicine [eletter]. http://www. annfammed.org/cgi/eletters/6/2/171\#8115, 14 Mar 2008.

36. Gadon ME. Life/work balance- every choice has its price [eletter]. http://www.annfammed.org/cgi/eletters/6/2/171\#8097, 11 Mar 2008.

37. Kjeldmand D, Holmström I. Balint groups as a means to increase job satisfaction and prevent burnout among general practitioners. Ann Fam Med. 2008;6(2):138-145

38. Benbassat J. Burnout among general practitioners [eletter]. http:// www.annfammed.org/cgi/eletters/6/2/138\#8239, 20 Mar 2008.

39. Brock CD, Freedy JR. Balint groups, academic rigor, and the doctorpatient relationship [eletter]. http://www.annfammed.org/cgi/eletters/6/2/138\#8253, 21 Mar 2008

40. Margalit APA. Balint group is one part of the whole [eletter]. http:// www.annfammed.org/cgi/eletters/6/2/138\#8297, 31 Mar 2008.

41. Buchbinder SB. Self-care for caregivers [eletter]. http://www. annfammed.org/cgi/eletters/6/2/138\#8140, 14 Mar 2008. 